\title{
The US Transuranium and Uranium Registries: forty years' experience and new directions in the analysis of actinides in human tissues
}

\author{
By S. Y. Tolmachev ${ }^{1, *}$, M. E. Ketterer ${ }^{2}$, D. Hare ${ }^{3}$, P. Doble ${ }^{3}$ and A. C. James ${ }^{1}$ \\ ${ }^{1}$ Washington State University, US Transuranium and Uranium Registries, 1845 Terminal Drive, Suite 201, Richland, WA 99354, USA \\ 2 Northern Arizona University, Department of Chemistry and Biochemistry, Box 5698, Flagstaff, AZ 86011, USA \\ ${ }^{3}$ University of Technology, Department of Chemistry and Forensic Science, Elemental Bio-imaging Facility, Sydney, Box 123, NSW 2007, \\ Australia
}

(Received December 23, 2009; accepted in revised form November 11, 2010)

Actinides / Human tissue / $\alpha$-Spectrometry / KPA / ICP-MS / Elemental bio-imaging

Summary. The US Transuranium and Uranium Registries (USTUR) studies the distribution, biokinetics and tissue dosimetry of actinide elements through radiochemical analysis of autopsy tissues voluntarily donated by occupationally exposed persons.

The paper provides an overview of the analytical methods for plutonium $(\mathrm{Pu})$, americium $(\mathrm{Am})$ and uranium (U) isotopic determination in human tissues currently applied at USTUR. The results of inter-comparing ${ }^{239+240} \mathrm{Pu},{ }^{241} \mathrm{Am}$ and ${ }^{234,235,238} \mathrm{U}$ determinations by sector field inductively coupled mass spectrometry (SF-ICP-MS), $\alpha$-spectrometry (AS) and kinetic phosphorescence analysis (KPA) are discussed. SFICP-MS is a major advance over AS and KPA in enabling the measurement of the ${ }^{240} \mathrm{Pu} /{ }^{239} \mathrm{Pu}$ atom ratio, the short-lived $\beta$-emitter ${ }^{241} \mathrm{Pu}$, and long-lived ${ }^{236} \mathrm{U}$. For the first time, ${ }^{241} \mathrm{Am}$ and ${ }^{241} \mathrm{Pu}$ were measured in human tissues using SF-ICP-MS.

The paper also presents a new avenue of USTUR research in the application of laser ablation inductively coupled plasma mass spectrometry (LA-ICP-MS) to elemental bio-imaging (EBI) of the actinides in human tissues.

\section{Introduction}

September 2008 was the $40^{\text {th }}$ anniversary of the US Atomic Energy Commission's vision in establishing the National Plutonium Registry. Its successors, the US Transuranium and Uranium Registries (USTUR), continue to follow individuals with documented accidental exposures to actinide elements, to study their uptake, translocation and retention (biokinetics), and tissue dosimetry. To date, 325 past-worker volunteers have donated their tissues for scientific research, including 36 whole body donors.

The Radiochemistry Program is an essential part of the USTUR as the quality of scientific data obtained relies on the quality of radiochemical analyses. The Health Safety and Environmental Division of the Los Alamos National Laboratory (LANL) started analyzing actinide elements in soft

\footnotetext{
*Author for correspondence (E-mail: stolmachev@ tricity.wsu.edu).
}

tissues and bones from former nuclear industry workers in 1959. In 1978 LANL started analyzing tissue samples obtained at autopsy by the Registries [1]. In 1992 the USTUR consolidated the Radiochemistry Program at the Nuclear Radiation Center, Washington State University (Pullman, WA). In 2006, this was relocated (temporarily) to Pasco, WA, and in 2009 to a new laboratory facility near the WSU Tri-Cities Campus (Richland, WA).

To date, more than 10000 human tissue samples have been analyzed for ${ }^{238} \mathrm{Pu},{ }^{239+240} \mathrm{Pu},{ }^{241} \mathrm{Am},{ }^{232} \mathrm{Th},{ }^{234} \mathrm{U},{ }^{235} \mathrm{U}$, ${ }^{238} \mathrm{U}$ isotopes and/or total U under the USTUR Program. Initially, the organs sampled were the lungs, tracheobronchial lymph nodes, liver and small pieces of bone [2]. Later, the number of samples collected from each donation was increased substantially [3]. The availability of the first whole body donation led to a comprehensive dissection protocol in which all major organs and tissues are sampled [4].

For the accurate and precise isotopic determination of the actinides, their pre-concentration and separation from the bone or soft tissue sample matrix is required. An appropriate sample aliquot is taken from the tissue solution for this actinide separation and quantitative analysis $[1,4,5]$. At LANL, a combination of several anion-exchange separation methods utilizing large $10-\mathrm{mL}$ chromatographic columns under gravity-flow and liquid-liquid extraction using dibutyl- $N, N$-diethylcarbamoyl phosphonate (DDCP) was used for uranium, plutonium and americium separation and determination in USTUR autopsy tissue samples [1,4-6]. On moving the USTUR Radiochemistry Program to WSU, the LANL methods were modified and/or replaced with new procedures, in order to improve actinide separation and to reduce the amount of mixed hazardous and radioactive waste. Separation methods based on extraction chromatography using smaller 2-mL columns of Actinide $\operatorname{Resin}^{\circledR}$, TEVA Resin ${ }^{\circledR}$ and TRU Resin ${ }^{\circledR}$ from Eichrom Technologies (Darien, IL, USA) were developed at WSU [7, 8]. Currently, a combination of extraction chromatography and anion-exchange methods is used for Pu and Am separation from acid dissolved human tissues [9-11]. Anion-exchange separation is used for U [12]. Similar procedures were applied by the Russian Dosimetry Registry of the Mayak 
Industrial Association (DRMIA) and National Radiation Protection Board (NRPB) in the UK for plutonium determination in autopsy tissues of occupationally exposed workers $[13,14]$. Radiochemical yields better than $70 \%$ and $80 \%$ are routinely achieved at USTUR for ${ }^{238} \mathrm{Pu},{ }^{239+240} \mathrm{Pu}$ and ${ }^{241} \mathrm{Am}$ analyses using ${ }^{242} \mathrm{Pu}$ and ${ }^{243} \mathrm{Am}$ as chemical recovery tracers. A ${ }^{232} \mathrm{U}$ radiochemical yield of $85 \%$ is generally obtained in uranium analyses. However, although the achieved recoveries are high, separation time, especially for $\mathrm{Pu} / \mathrm{Am}$ determination is long and a substantial amount of acid waste is produced.

During the past decade new types of extraction chromatographic resins have been developed $[15,16]$ and successfully applied to actinide separation and determination in biological and bioassay samples [17-21]. Implementation of vacuum-assisted extraction chromatographic separation in place of the conventional gravity-flow separation approach significantly reduces the time needed for separation $[18,22-24]$. The separation procedure recently developed for actinide and strontium determination in fish and animal tissues [18] has recently been tested at USTUR for plutonium isotopic and ${ }^{241} \mathrm{Am}$ separation and determination in human bone and soft tissue samples, in combination with $\alpha$-spectrometry (AS). This method uses stacked Eichrom's TEVA Resin ${ }^{\circledR}$, TRU Resin ${ }^{\circledR}$ and DGA Resin ${ }^{\circledR}$ cartridges, and enables the rapid separation of $\mathrm{Pu}, \mathrm{Np}, \mathrm{U}, \mathrm{Am}$, and $\mathrm{Cm}$ using a single multi-stage column on a vacuum box. Significant improvements in $\mathrm{Pu}$ and $\mathrm{Am}$ analyses were achieved with this new method. Thus, radiochemical recoveries greater than $90 \%$ and $95 \%$ were routinely obtained for $\mathrm{Pu}$ and $\mathrm{Am}$ respectively for both bone and soft tissue samples.

Today, $\alpha$-spectrometry (AS) is the most widely used radiometric technique for low-level detection of ${ }^{234} \mathrm{U},{ }^{235} \mathrm{U}$, ${ }^{238} \mathrm{U},{ }^{238} \mathrm{Pu},{ }^{239+240} \mathrm{Pu}$ and ${ }^{241} \mathrm{Am}$ isotopes in human tissue samples [25-28]. At USTUR, AS is used for ${ }^{238} \mathrm{Pu}$, ${ }^{239+240} \mathrm{Pu},{ }^{241} \mathrm{Am},{ }^{234} \mathrm{U},{ }^{235} \mathrm{U}$ and ${ }^{238} \mathrm{U}$ activity determination. To prepare $\alpha$-spectrometric counting sources, the purified actinide fraction is electrodeposited from a sulfate medium on a stainless steel disk. The electrodeposition conditions currently used by USTUR [29] were optimized from LANL's original method [30] by chemometric analysis [31]. Prepared $\alpha$-sources are counted using a $450 \mathrm{~mm}^{2} \mathrm{Si}(\mathrm{Au})$ surface barrier detector for $150000 \mathrm{~s}$ with $300000 \mathrm{~s}$ counting time for the background. Thirty two detectors are available at USTUR. Of these, 24 detectors are dedicated for Am and/or Pu isotopes measurement and 8 are used for $\mathrm{U}$ and/or Th determination. The limit of detection (LOD) for the actinides is typically $\sim 0.3 \mathrm{mBq}$. The overall uncertainty in AS measurements is routinely calculated with error propagation rules taking into account the uncertainty of mass measurements, tracer concentrations, detector calibration and counting statistics.

For uranium determination at low levels, kinetic phosphorescence analysis (KPA) is often used as a rapid alternative to AS [32-34]. Both $\alpha$-spectrometry and KPA have limitations and advantages. While AS has a radiometric detection limit for ${ }^{238} \mathrm{U}$ of $\sim 0.3 \mathrm{mBq}$, in terms of mass, this is relatively high $(27 \mathrm{ng})$. Another disadvantage of AS is the long counting time, which may be days to weeks, depending on the activity of the sample and the precision required. KPA, on the other hand, has a detection limit three orders of magnitude lower $(0.02 \mathrm{ng})$ and a short analysis time. However, the application of KPA is limited by the small amount of sample analyzed (restricted to a 1-mL aliquot), by phosphorescence degradation by salts in solution, and by the fact that no isotopic information is obtainable. Moreover, the KPA method does not provide chemical recovery information.

A recovery corrected KPA method for the determination of total uranium in human tissues was developed at WSU $[35,36]$. This method combined pre-concentration of $\mathrm{U}$ from a large aliquot $(50 \mathrm{~mL})$ of tissue solution (in $6 \mathrm{M}$ $\mathrm{HCI}$ ) by anion exchange with AS and KPA, utilizing ${ }^{232} \mathrm{U}$ as a chemical recovery tracer. The radiochemical yield of ${ }^{232} \mathrm{U}$ was determined by AS and the total uranium content was determined by KPA.

Inductively coupled plasma mass spectrometry (ICPMS), particularly with sector field mass analyzers (SF-ICPMS), has emerged in the past several years as an excellent analytical technique for rapid, highly sensitive determination of radionuclides, including uranium and transuranic elements, mainly in environmental samples [37-39]. SFICP-MS has the advantages of simplicity of sample preparation, high sample throughput and relatively straightforward operation when compared to other competing mass spectrometric techniques such as thermal ionization mass spectrometry (TIMS) and accelerator mass spectrometry (AMS). Arguably, SF-ICP-MS is the preferred technique for routine, high-throughput determination of ${ }^{237} \mathrm{~Np}, \mathrm{U}$ and $\mathrm{Pu}$ isotopes, excepting ${ }^{238} \mathrm{Pu}$, at $10^{-15}-10^{-12} \mathrm{~g}$ levels.

A significant advantage of ICP-MS is its capability to measure the ${ }^{239} \mathrm{Pu} /{ }^{240} \mathrm{Pu}$ isotopic ratio, which could not be measured by AS because of the indistinguishable main $\alpha$ particle energies $\left(5.157 \mathrm{MeV}\right.$ and $5.168 \mathrm{MeV}$ for ${ }^{239} \mathrm{Pu}$ and ${ }^{240} \mathrm{Pu}$, respectively). This ratio serves as an isotopic signature of the Pu origin [40], i.e., whether the Pu came from atmospheric testing of nuclear weapons (global fallout), weapongrade or nuclear fuel Pu. Furthermore, using SF-ICP-MS, the short-lived $\beta$-emitter ${ }^{241} \mathrm{Pu}\left(T_{1 / 2}=14.35 \mathrm{y}\right)$ and ${ }^{241} \mathrm{Am}$ can be measured [41-43]. For uranium, the anthropogenic ${ }^{236} \mathrm{U}$ isotope can also be precisely measured using SF-ICPMS $[44,45]$. This paper describes the extension of the SFICP-MS technique developed for environmental samples to the analysis of actinides in human tissues.

Elemental bio-imaging (EBI) is a potential application of laser ablation-inductively coupled plasma-mass spectrometry (LA-ICP-MS) to the study of actinide distributions in human tissue samples. EBI allows for in situ analysis of trace elements at high resolution, with the potential to provide not just qualitative but quantitative spatial (two and three-dimensional) concentration data. Briefly, a focused laser beam is directed onto the surface of a tissue sample, and the ablated material is transported to the ICP-MS by a carrier gas. By traversing the laser beam across the sample, the resultant mass spectra can be combined into twodimensional maps displaying the relative intensity of measured isotopes throughout the tissue section. Quantitative data can be recorded by the ablation of matrix-matched tissue standards and construction of multi-point calibration curves. The EBI technique has been applied to the analysis of stable elements (such as $\mathrm{Ca}, \mathrm{Mg}, \mathrm{P}$ ) in human osteoarthritic tissue [46] and human melanoma samples [47]. A similar 
technique has been used for imaging $\mathrm{Cu}, \mathrm{Zn}, \mathrm{Pb}$ and $\mathrm{U}$ in human brain tumor resections [48] and $U$ in rat brain sections [49]. The EBI technique has recently been extended to actinide isotopic $\left({ }^{232} \mathrm{Th},{ }^{235} \mathrm{U},{ }^{238} \mathrm{U}\right.$ and $\left.{ }^{239} \mathrm{Pu}\right)$ imaging in lymph nodes from former nuclear workers [50].

\section{Experimental}

\subsection{Sample selection and description}

To test the capability of SF-ICP-MS for ${ }^{234,235,238} \mathrm{U},{ }^{239+240} \mathrm{Pu}$ and ${ }^{241} \mathrm{Am}$ determination in human tissues, sample solutions were selected from 8 digested bones and 11 soft tissues from 4 wholebody donations, previously analyzed at USTUR. The tissue samples used are listed (by USTUR case number) in Tables 1 and 2, with the ${ }^{239+240} \mathrm{Pu},{ }^{241} \mathrm{Am}$ and ${ }^{234,235,238} \mathrm{U}$ activity concentrations ( $\mathrm{Bq} \mathrm{kg}^{-1}$ of wet tissue weight) measured by both AS and SF-ICP-MS. USTUR cases 0269, 0425 and 0720 had known accidental plutonium exposures. Case 0269 was an acute inhalation intake of soluble $\mathrm{Pu}\left(\mathrm{NO}_{3}\right)_{4}$. Cases 0425 and 0720 involved inhalation intakes of refractory $\mathrm{PuO}_{2}$ particles. Activity concentrations of ${ }^{238} \mathrm{Pu}$, ${ }^{239+240} \mathrm{Pu}$ and ${ }^{241} \mathrm{Am}$ were measured using the established USTUR radioanalytical protocol and $\alpha$-spectrometry [9-11, 29]. USTUR Registrant Case 1028 was exposed to highly enriched uranium (HEU), primarily through inhalation. The ${ }^{234} \mathrm{U},{ }^{235} \mathrm{U}$, and ${ }^{238} \mathrm{U}$ activity concentrations were measured by AS after uranium chemical separation [12,29].

Registrant Case 0425 had no history of occupational exposure to $\mathrm{U}$, and total uranium concentration was measured using the KPA recovery corrected method. The uranium was previously confirmed to be of natural composition by AS, i.e., the ${ }^{234} \mathrm{U} /{ }^{238} \mathrm{U}$ activity ratio $\sim 1$ [51].

A pulmonary lymph node (LN) from USTUR Case 0846 was selected for elemental bio-imaging of actinides in human tissues using LA-ICP-MS. The LN sample was fixed

Table 1. The results of $\mathrm{Pu}$ isotopes and ${ }^{241} \mathrm{Am}$ determination in selected human tissues with $\alpha$-spectrometry and SF-ICP-MS.

\begin{tabular}{|c|c|c|c|c|c|c|}
\hline \multirow[t]{2}{*}{ Tissue } & \multicolumn{2}{|c|}{${ }^{239+240} \mathrm{Pu}, \mathrm{Bq} \mathrm{kg}^{-1}$} & \multirow{2}{*}{$\begin{array}{c}{ }^{240} \mathrm{Pu} /{ }^{239} \mathrm{Pu} \\
\text { atom ratio }\end{array}$} & \multirow[t]{2}{*}{${ }^{241} \mathrm{Pu}, \mathrm{Bq} \mathrm{kg}^{-1}$} & \multicolumn{2}{|c|}{${ }^{241} \mathrm{Am}, \mathrm{Bq} \mathrm{kg}^{-1}$} \\
\hline & $\alpha$-spectrometry & SF-ICP-MS & & & $\alpha$-spectrometry & SF-ICP-MS \\
\hline \multicolumn{7}{|l|}{ Case 0269} \\
\hline Lung (R) & $23.8 \pm 0.3$ & $29.0 \pm 0.3$ & $0.062 \pm 0.002$ & & $4.6 \pm 0.1$ & \\
\hline Liver & $923.5 \pm 22.2$ & $1023.3 \pm 5.0$ & $0.063 \pm 0.001$ & $580.6 \pm 63.0$ & $70.2 \pm 1.6$ & $72.8 \pm 2.6$ \\
\hline Femur (R) PE & $153.0 \pm 2.5$ & $161.7 \pm 2.1$ & $0.063 \pm 0.001$ & $95.4 \pm 29.0$ & $39.9 \pm 0.9$ & \\
\hline Humerus (R) PE & $147.9 \pm 2.4$ & $149.0 \pm 2.1$ & $0.063 \pm 0.001$ & $99.5 \pm 5.7$ & $38.3 \pm 0.8$ & $34.1 \pm 4.6$ \\
\hline \multicolumn{7}{|c|}{ Case 0425} \\
\hline Liver & $8.5 \pm 0.2$ & $8.9 \pm 0.2$ & $0.062 \pm 0.001$ & & $0.88 \pm 0.04$ & \\
\hline Bladder Gall & $0.15 \pm 0.04$ & n.d. & n.d. & & $0.006 \pm 0.004$ & \\
\hline Spleen & $5.7 \pm 0.1$ & $6.1 \pm 0.1$ & $0.064 \pm 0.002$ & & $1.18 \pm 0.06$ & \\
\hline Kidney (R) & $0.17 \pm 0.02$ & $0.17 \pm 0.01$ & $0.080 \pm 0.020$ & & $0.006 \pm 0.004$ & \\
\hline Fibula (R) PE & $1.5 \pm 0.1$ & $1.4 \pm 0.1$ & $0.080 \pm 0.040$ & & $0.74 \pm 0.08$ & \\
\hline Scapula, spine & $3.1 \pm 0.3$ & $3.0 \pm 0.1$ & $0.068 \pm 0.001$ & & $1.3 \pm 0.2$ & \\
\hline Sacrum & $3.6 \pm 0.2$ & $3.7 \pm 0.1$ & $0.062 \pm 0.002$ & & $1.10 \pm 0.09$ & \\
\hline \multicolumn{7}{|l|}{ Case 0720} \\
\hline Lung (R) & $145.2 \pm 4.7$ & $155.8 \pm 0.7$ & $0.063 \pm 0.001$ & $137.0 \pm 5.0$ & $31.8 \pm 1.0$ & $29.2 \pm 0.7$ \\
\hline Liver & $68.5 \pm 2.0$ & $67.7 \pm 0.2$ & $0.059 \pm 0.001$ & $54.4 \pm 8.1$ & $4.1 \pm 0.2$ & $3.8 \pm 0.2$ \\
\hline
\end{tabular}

$\mathrm{R}$ - right side; PE - proximal end; n.d. - not detected.

Table 2. The results of $U$ isotopes determination in selected human tissues using KPA, $\alpha$-spectrometry and SF-ICP-MS

\begin{tabular}{|c|c|c|c|c|}
\hline \multirow[t]{2}{*}{ Tissue } & \multicolumn{3}{|c|}{${ }^{234,235,238} \mathrm{U}, \mathrm{Bq} \mathrm{kg}^{-1}$} & \multirow{2}{*}{$\begin{array}{l}{ }^{236} \mathrm{U} /{ }^{238} \mathrm{U}, \\
\text { atom ratio }\end{array}$} \\
\hline & KPA & SF-ICP-MS & $\alpha$-spectrometry & \\
\hline \multicolumn{5}{|l|}{ Case 0425} \\
\hline Liver & $0.0060 \pm 0.0002$ & $0.0048 \pm 0.0006$ & & \\
\hline Bladder Gall & $0.037 \pm 0.001$ & $0.041 \pm 0.007$ & & \\
\hline Spleen & $0.0149 \pm 0.0004$ & $0.015 \pm 0.001$ & & \\
\hline Kidney (R) & $0.0282 \pm 0.0007$ & $0.028 \pm 0.002$ & & \\
\hline Fibula (R) PE & $0.098 \pm 0.003$ & $0.093 \pm 0.005$ & & \\
\hline Scapula, spine & $0.129 \pm 0.003$ & $0.129 \pm 0.009$ & & \\
\hline Sacrum & $0.0407 \pm 0.0009$ & $0.0347 \pm 0.0009$ & & \\
\hline \multicolumn{5}{|l|}{ Case 1028} \\
\hline Lung (R) & & $29.5 \pm 0.9$ & $29.4 \pm 0.7$ & $0.00606 \pm 0.00011$ \\
\hline Spleen & & $0.045 \pm 0.012$ & $0.061 \pm 0.006$ & $0.00091 \pm 0.00006$ \\
\hline Kidney (R) & & $0.59 \pm 0.02$ & $0.66 \pm 0.03$ & $0.00150 \pm 0.00020$ \\
\hline Femur (R) MS & & $6.8 \pm 0.1$ & $6.5 \pm 0.2$ & $0.00606 \pm 0.00008$ \\
\hline Ulna (R) DS & & $0.77 \pm 0.04$ & $0.82 \pm 0.04$ & $0.00425 \pm 0.00008$ \\
\hline Humerus (L) DE & & $11.9 \pm 0.3$ & $11.5 \pm 0.3$ & $0.00598 \pm 0.00003$ \\
\hline
\end{tabular}

$\mathrm{R}$ - right side; L - left side; PE - proximal end; MS - middle shaft; DS - distal shaft; DE - distal end. 
in $10 \%$ buffered formalin and shipped to the Elemental Bioimaging facility at the University of Technology, Sydney. This Registrant whole-body donor passed away at age 72, four decades after exceptionally high, chronic inhalation exposure to ${ }^{241} \mathrm{AmO}_{2}$ (1964-1967). The ${ }^{241} \mathrm{Am}$ body burden was estimated to be about $67 \mathrm{kBq}$, i.e., 36 times the then-recommended maximum permissible body burden for americium [52]. Such a deposition was the highest body content of a radionuclide of the plutonium-americium radiotoxicity family known at that time to have been deposited in a person in the United States. A lymph node from this case was selected because this would have accumulated deposited particles, and would be expected to provide the highest ${ }^{241} \mathrm{Am}$ concentration of any organ, and thus the highest chance of detection by LA-ICP-MS.

\subsection{Reagents and materials}

${ }^{242} \mathrm{Pu}$ prepared from NIST SRM $4334 \mathrm{G}$ (USA), ${ }^{243} \mathrm{Am}$ obtained from USEPA-Las Vegas (USA), and isotopic standard ${ }^{236} \mathrm{U}$ received from the University of Liverpool (UK) were used to spike the samples for SF-ICP-MS determination of ${ }^{239+240} \mathrm{Pu},{ }^{241} \mathrm{Pu},{ }^{241} \mathrm{Am}$ and ${ }^{234} \mathrm{U},{ }^{235} \mathrm{U},{ }^{238} \mathrm{U}$, respectively. A natural uranium solution was used to correct for SF-ICPMS instrumental mass discrimination. Th and $\mathrm{U}$ standards of $100 \mathrm{mg} \mathrm{L}^{-1}$ in $5 \% \mathrm{HNO}_{3}$ (Choice Analytical, Thornleigh, NSW, Australia) were used to prepare mixed standards for quantification of the LA-ICP-MS measurements. The UTEVA Resin ${ }^{\circledR}$, TEVA Resin ${ }^{\circledR}$ and branched DGA Resin ${ }^{\circledR}$ of 50-100 $\mu \mathrm{m}$ particle size from Eichrom Technologies Inc. (Darien, Illinois, USA) were used for actinide separations. Nitric and hydrochloric acids were prepared from A.C.S. reagent grade concentrated acids (J.T. Baker, USA). All water was obtained from a Milli-Q2 ${ }^{\mathrm{TM}}$ water purification system. All other materials were A.C.S. reagent grade and were used as received.

\subsection{ICP-MS instrumentation}

The SF-ICP-MS instrument used in this study for actinide isotope determination was a VG Axiom MC inductively coupled plasma mass spectrometer (Thermo Elemental, Winsford, Cheshire, UK) The instrument was equipped with a U-5000AT ultrasonic nebulizer (CETAC Technologies, Omaha, NE, USA) operated at $500 \mu \mathrm{L} \mathrm{min}^{-1}$ sample solution uptake flow rate. The SF-ICP-MS installed in the Department of Chemistry and Biochemistry, Northern Arizona University, Flagstaff, USA was used in the singlecollector, electron multiplier mode with magnetic field scanning. The general characteristics of this system and its use in $\mathrm{Pu}$ analysis of environmental samples are discussed elsewhere $[53,54]$.

For elemental bio-imaging studies, LA-ICP-MS measurements were carried out using a New Wave UP-213 laser ablation unit (Kenelec Technologies, Mitcham, Victoria, Australia), installed at the Elemental Bio-Imaging Facility, University of Technology, Sydney, Australia. The UP-213 emits a $213 \mathrm{~nm}$ laser pulse from a Nd:YAG solid state gain medium. The laser unit was connected to an Agilent Technologies 7500ce quadrupole ICP-MS (Forrest Hill, Victoria, Australia) with a 'cs' lens system for enhanced sensitivity.
The instrumental operating conditions are described in detail elsewhere [47].

\subsection{Separation of $\mathrm{Pu}, \mathrm{Am}$ and $\mathrm{U}$ using extraction chromatography}

Prior to SF-ICP-MS measurements, actinides were separated from sample solution aliquots using extraction chromatography. All sample dilutions were prepared gravimetrically.

\subsubsection{Extraction chromatography for Pu determinations}

USTUR sample solution aliquots of 14-17 gram were spiked with $14.08 \mathrm{mBq}$ of ${ }^{242} \mathrm{Pu}$. Sample aliquots of 0.28 and 0.30 gram were taken for lung and liver samples from Case 0269 , diluted with $15 \mathrm{~mL}$ of $6 \mathrm{M} \mathrm{HCl}$ and spiked with $14.08 \mathrm{mBq}$ of ${ }^{242} \mathrm{Pu}$, and processed in the same manner. Samples were heated in a convection oven at $75^{\circ} \mathrm{C}$ for $2.5 \mathrm{~h}$ to facilitate sample-spike equilibration. One $\mathrm{mL}$ of freshly prepared $0.25 \mathrm{M} \mathrm{NaNO}_{2}$ solution was added to each sample aliquot to stabilize Pu(IV), and $50 \mathrm{mg}$ of TEVA Resin ${ }^{\circledR}$ was then added. The mixtures were capped and agitated gently for $2.5 \mathrm{~h}$ on an orbital shaker to achieve an equilibrium batch-mode distribution of $\mathrm{Pu}$ between the resin and solution. Thereafter, the TEVA Resin ${ }^{\circledR}$ was collected from each solution on a $10 \mathrm{~mL}$ polypropylene pipette tip "column" equipped with a glass wool plug; the resin was retained and the pass-through solution was discarded. Each column was rinsed 3 times with $2 \mathrm{~mL}$ of $8 \mathrm{M} \mathrm{HCl}$ and 3 times with $2 \mathrm{~mL}$ of $2 \mathrm{M} \mathrm{HNO}_{3}$. Rinsing solutions were discarded. $\mathrm{Pu}$ was eluted and collected with the following sequence: $2 \mathrm{~mL} \mathrm{H}_{2} \mathrm{O}, 2 \mathrm{~mL}$ of $0.05 \mathrm{M}$ aqueous ammonium oxalate, and $2 \mathrm{~mL} \mathrm{H}_{2} \mathrm{O}$, all of which were combined in one "Pu fraction". The Pu fraction was directly submitted for SF-ICP-MS measurement.

\subsubsection{Extraction chromatography for ${ }^{241} \mathrm{Am}$ determination}

Sample aliquots of $5 \mathrm{~g}$ nominal mass were spiked with $8.34 \mathrm{mBq}$ of ${ }^{243} \mathrm{Am}$. One $\mathrm{mL}$ of freshly prepared $0.25 \mathrm{M}$ $\mathrm{NaNO}_{2}$ solution was added to each sample aliquot and the mixtures were heated in a convection oven at $75^{\circ} \mathrm{C}$ for $2.5 \mathrm{~h}$ to facilitate conversion to $\mathrm{Pu}(\mathrm{IV})$. The solution was passed through a 30-mg TEVA Resin ${ }^{\circledR}$ micro-column. The passthrough solution (stripped of $\mathrm{Pu}$ ) was collected and passed through a 30 -mg UTEVA Resin ${ }^{\circledR}$ micro-column. The solution passing through the UTEVA Resin ${ }^{\circledR}$ was finally passed through a branched DGA Resin ${ }^{\circledR}$ micro-column. Each DGA Resin ${ }^{\circledR}$ column was rinsed twice with $0.5 \mathrm{~mL}$ of $8 \mathrm{M} \mathrm{HCl}$ followed by 4 times with $0.5 \mathrm{~mL}$ of $8 \mathrm{M} \mathrm{HNO}_{3}$. Rinsing solutions were discarded. Finally, Am was eluted and collected with $5 \mathrm{~mL}$ of $0.1 \mathrm{M} \mathrm{HNO}_{3}$ that was submitted for SF-ICPMS measurement.

\subsubsection{Extraction chromatography for $U$ determinations}

Sample aliquots of 5 gram nominal mass were spiked with approximately $25 \mathrm{pg}$ of ${ }^{236} \mathrm{U}$. Although this addition was reproducible, and performed in the same manner as the standards, knowledge of the exact amount was not necessary 
because calculations were performed using ${ }^{236} \mathrm{U}$ as an internal standard (rather than as a spike in isotope dilution). Then $20 \mathrm{mg}$ of UTEVA Resin ${ }^{\circledR}$ was added to each sample solution, and the mixtures were agitated gently for $2.5 \mathrm{~h}$ on an orbital shaker to achieve an equilibrium batch-mode distribution of $U$ between the resin and solution. Thereafter, the UTEVA Resin ${ }^{\circledR}$ was collected from each solution on a 10-mL polypropylene pipette tip "column" equipped with a glass wool plug; the resin was retained and the passthrough solution was discarded. Each column was rinsed as follows: 3 times with $1 \mathrm{~mL}$ of $6 \mathrm{M} \mathrm{HCl}$, and 3 times with $1 \mathrm{~mL}$ of $2 \mathrm{M} \mathrm{HNO}_{3}$. Finally, $\mathrm{U}$ was eluted from the column and collected with the following sequence: $1 \mathrm{~mL} \mathrm{H}_{2} \mathrm{O}, 1 \mathrm{~mL}$ of $0.05 \mathrm{M}$ aqueous ammonium oxalate, and $1 \mathrm{~mL} \mathrm{H}_{2} \mathrm{O}$, all of which were combined in one "U fraction". The U fraction was submitted directly for SF-ICP-MS analysis.

\subsection{SF-ICP-MS measurement}

Inductively coupled plasma mass spectrometric measurements of ${ }^{239} \mathrm{Pu},{ }^{240} \mathrm{Pu},{ }^{241} \mathrm{Pu}$ and ${ }^{241} \mathrm{Am}$ were performed in low resolution mode $(m / \Delta m=400$ at $10 \%$ height). Concentrations of isotopes of interest were calculated based on measured ${ }^{239} \mathrm{Pu} /{ }^{242} \mathrm{Pu},{ }^{240} \mathrm{Pu} /{ }^{242} \mathrm{Pu},{ }^{241} \mathrm{Pu} /{ }^{242} \mathrm{Pu}$ and ${ }^{241} \mathrm{Am} /{ }^{243} \mathrm{Am}$ atom ratios, using the isotope dilution method [55]. The ${ }^{238} \mathrm{U} /{ }^{235} \mathrm{U}$ ratio was measured in a natural U solution $\left(0.2 \mu \mathrm{g} \mathrm{L}^{-1}\right)$ to develop a mass bias correction factor:

$$
\mathrm{MBF}=\left[\left({ }^{238} \mathrm{U} /{ }^{235} \mathrm{U}\right)_{\text {meas }} / 137.88\right]^{1 / 3}
$$

where 137.88 is the atom ratio for naturally occurring $\mathrm{U}$.

For ${ }^{241} \mathrm{Am}$ determination, the ${ }^{240} \mathrm{Pu}^{+}$intensity was monitored in order to perform a subtractive correction for any ${ }^{241} \mathrm{Pu}^{+}$isobar contribution to the ${ }^{241} \mathrm{Am}^{+}$signal. This correction is based upon the ${ }^{241} \mathrm{Pu} /{ }^{240} \mathrm{Pu}$ atom ratio measured in the $\mathrm{Pu}$ analysis:

$$
{ }^{241} \mathrm{Am}_{\text {corrected }}={ }^{241} \mathrm{Am}_{\text {raw }}-\left({ }^{241} \mathrm{Pu} /{ }^{240} \mathrm{Pu}\right)_{\text {meas }} \times{ }^{241} \mathrm{Pu}_{\mathrm{Am}}
$$

where ${ }^{241} \mathrm{Pu}_{\mathrm{Am}}$ is ${ }^{241} \mathrm{Pu}$ signal in the Am fraction.

Concentrations of $\mathrm{U}$ isotopes were determined using internal standardization with ${ }^{236} \mathrm{U}$. Standards were prepared to contain ${ }^{236} \mathrm{U}$ at an amount identical to each pre-column sample. Samples from USTUR Case 1028 contained ${ }^{236} U$ in the original (unspiked) samples. In order to correct for this in using ${ }^{236} \mathrm{U}$ as an internal standard, the Case 1028 samples were prepared in duplicate, one each with ${ }^{236} \mathrm{U}$ added and one without added ${ }^{236} \mathrm{U}$. The results of the unspiked samples were used to calculate the native ${ }^{236} \mathrm{U} /{ }^{238} \mathrm{U}$ atom ratio in the sample. This ratio was used to determine the ${ }^{236} \mathrm{U}$ signal due to indigenous ${ }^{236} \mathrm{U}$, and the indigenous-subtracted ${ }^{236} \mathrm{U}$ signal was used for subsequent $U$ activity calculations.

All individual isotopic concentrations were reported with one standard deviation $(1 \sigma)$ of the three replicate measurements for each specific sample.

The method limits of detection (LOD) for Pu and U determinations were obtained through analysis of three preparation blanks. For $\mathrm{Pu}$, preparation blanks were produced using $15 \mathrm{~g}$ of $6 \mathrm{M} \mathrm{HCl}$ solution. The blanks were prepared and analyzed in exactly the same manner, simultaneously with the unknown samples. The average blank activity results were subtracted from the activity results for each sample. The detection limit was calculated as six times the standard deviation $(6 \sigma)$ of the average activity results from the three individual blanks. A more conservative $6 \sigma$-definition has been used, instead of the generally applied $3 \sigma$-criterion, since only a small set of blanks was processed. For Am, a very limited set of one blank and six unknown samples has been analyzed in the study. Therefore, similar statistics are not possible with multiple blanks. However, the ${ }^{241} \mathrm{Am}$ LOD was estimated as six times the standard deviation $(6 \sigma)$ of the activity results from the three integrations of the single preparation blank.

\subsection{LA-ICP-MS measurement}

Typical LA-ICP-MS measurement conditions for actinide bio-imaging in human tissues are given in details elsewhere [50]. The LA-ICPMS system was tuned for maximum sensitivity prior to each experiment using NIST 612 Trace Elements in glass. NIST glass was also used to ensure low oxide production. The $248 / 232\left(\mathrm{ThO}^{+} / \mathrm{Th}^{+}\right)$ratio was consistently less than $0.3 \%$. The laser energy density was maintained at $0.3 \mathrm{~J} \mathrm{~cm}^{-2}$. The laser frequency was $20 \mathrm{~Hz}$. A laser spot size of $65 \mu \mathrm{m}$ and scan speed of $65 \mu \mathrm{m} \mathrm{s}^{-1}$ was used to ensure that the true image resolution was as close to $65 \mu \mathrm{m}$ as possible. Laser spot diameter of $65 \mu \mathrm{m}$ was also selected to obtain a good balance between image resolution and sample run time, which was up to $24 \mathrm{~h}$, depending on the sample size.

Images were subsequently produced using in-house ISIDAS (Interactive Spectral Imaging Data Analysis Software). These images were exported from ISIDAS as Visualisation Toolkit (.vtk) files into the MayaVi2 (Enthought, Inc., Austin, Texas, USA) for final image rendition.

\subsection{Data analysis}

The isotopic mass concentrations of ${ }^{239} \mathrm{Pu},{ }^{240} \mathrm{Pu},{ }^{241} \mathrm{Pu}$, ${ }^{241} \mathrm{Am}$ and ${ }^{234} \mathrm{U},{ }^{235} \mathrm{U},{ }^{238} \mathrm{U}$ measured by SF-ICP-MS were converted to isotopic activity concentrations using the specific activity $\left(\mathrm{Bq} \mathrm{g}^{-1}\right)$ of each isotope [56]. The ${ }^{239+240} \mathrm{Pu}$ activity concentration was calculated as the sum of ${ }^{239} \mathrm{Pu}$ and ${ }^{240} \mathrm{Pu}$ activity concentrations, and the total uncertainty was propagated. That value was compared with ${ }^{239+240} \mathrm{Pu}$ activity concentration measured directly by AS for the same sample. For uranium analyses, to compare the results of AS and KPA with SF-ICP-MS, ${ }^{234,235,238} \mathrm{U}$ activity concentrations in tissue were first calculated as a sum of ${ }^{234} U,{ }^{235} U$ and ${ }^{238} \mathrm{U}$ individual activity concentrations measured directly by AS. Since KPA does not provide isotopic composition information, the ${ }^{234,235,238} \mathrm{U}$ activity concentrations were calculated using measured total $\mathrm{U}$ mass concentrations and the natural U specific activity. For SF-ICP-MS measurements, the ${ }^{234} \mathrm{U},{ }^{235} \mathrm{U}$, and ${ }^{238} \mathrm{U}$ atom concentrations were converted to individual isotopic activity concentrations using specific activities for ${ }^{234} U,{ }^{235} U$ and ${ }^{238} U$ isotopes [56], and summed to calculate ${ }^{234,235,238} \mathrm{U}$ activity concentrations.

The Wilcoxon matched-pairs test was performed to evaluate statistical difference between concentration data sets. 
The test was performed at $95 \%$ significance level and statistical significance was concluded when the $p$-value was $<0.05$ [57]. Weighted regression analysis was performed to compare entire data sets for ${ }^{239+240} \mathrm{Pu},{ }^{241} \mathrm{Am}$ and ${ }^{234,235,238} \mathrm{U}$ tissue activity concentrations. Goodness of data fit was judged based on the regression slope $(a)$, y-axis intercept $(b)$ and the correlation coefficient $\left(R^{2}\right)$.

\section{Results and discussion}

\subsection{Analytical figures of merit}

The extraction chromatography actinide separation schemes used were demonstrated to be acceptable for the sample matrices encountered, when using SF-ICP-MS as the determination technique. Recoveries, although not quantitatively measured, are estimated to vary between $20-60 \%$ with lower recoveries observed for bone samples.

For the SF-ICP-MS instrument, the mass bias factor (MBF) was typically $1.005-1.010$. For ${ }^{239} \mathrm{Pu}$ determination, ${ }^{238} \mathrm{U}^{1} \mathrm{H}^{+} /{ }^{238} \mathrm{U}^{+}$"hydride" ratio was measured to correct for isobaric interference. It was typically $0.00002-0.00004$ for the ultrasonic sample introduction system, and thus $\mathrm{UH}^{+}$ correction is relatively unimportant for most samples, provided that ubiquitous $U$ has been sufficiently eliminated by the column chemistry.

The SF-ICP-MS limits of detection (LOD) obtained in this study were $0.1 \mathrm{mBq}, 30 \mathrm{mBq}$ and $0.35 \mathrm{mBq}$ for ${ }^{239+240} \mathrm{Pu},{ }^{241} \mathrm{Pu}$ and ${ }^{241} \mathrm{Am}$, respectively. The SF-ICP-MS LODs for ${ }^{239+240} \mathrm{Pu}$ and ${ }^{241} \mathrm{Am}$ are comparable with $0.3 \mathrm{mBq}$ generally obtained at USTUR with $\alpha$-spectrometry for these isotopes. For ${ }^{234} \mathrm{U},{ }^{235} \mathrm{U}$ and ${ }^{238} \mathrm{U}$ isotopes, LODs of $0.1 \mathrm{mBq}, 0.006 \mathrm{mBq}$ and $0.09 \mathrm{mBq}$ were achieved with SF-ICP-MS. These LODs are significantly lower than the $0.3 \mathrm{mBq}$ achieved at USTUR for the uranium isotopes by AS. For total U determination, KPA is a most sensitive technique. With KPA, LOD of $0.0005 \mathrm{mBq}(0.02 \mathrm{ng})$ for natural composition U was routinely achieved at USTUR $[35,36]$.

\subsection{Comparison of SF-ICP-MS vs. AS and KPA for $\mathrm{Pu}, \mathrm{Am}$ and $\mathrm{U}$ determination}

The results of ${ }^{239+240} \mathrm{Pu}$ and ${ }^{241} \mathrm{Am}$ activity concentrations measured in digested human soft tissues and bones by $\alpha$ spectrometry (AS) and SF-ICP-MS; along with ${ }^{240} \mathrm{Pu} /{ }^{239} \mathrm{Pu}$ atom ratio and ${ }^{241} \mathrm{Pu}$ results are given in Table 1 . Table 2 compares results for ${ }^{234,235,238} \mathrm{U}$ total activity concentrations measured by KPA, AS and SF-ICP-MS, and ${ }^{236} \mathrm{U} /{ }^{238} \mathrm{U}$ atom ratios measured by SF-ICP-MS.

With SF-ICP-MS, ${ }^{239+240} \mathrm{Pu}$ activity concentrations and ${ }^{240} \mathrm{Pu} /{ }^{239} \mathrm{Pu}$ atom ratios were measured in 12 of 13 samples. The ${ }^{240} \mathrm{Pu} /{ }^{239} \mathrm{Pu}$ atom ratio ranged from 0.059 to 0.080 . The average ${ }^{240} \mathrm{Pu} /{ }^{239} \mathrm{Pu}$ atom ratio for 10 tissue samples was $0.0629 \pm 0.0013$ (at the $95 \%$ confidence interval). The two ${ }^{240} \mathrm{Pu} /{ }^{239} \mathrm{Pu}$ ratio values of 0.080 , measured in samples with lowest ${ }^{239+240} \mathrm{Pu}$ concentrations, were excluded from the calculation of the average, since their associated relative errors were greater than $25 \%$. The measured ${ }^{240} \mathrm{Pu} /{ }^{239} \mathrm{Pu}$ atom ratio clearly indicates exposure to weapon-grade $\mathrm{Pu}[40]$.

The concentration of ${ }^{241} \mathrm{Pu}$ was measured by SF-ICP-MS in 5 "high Pu" samples, and ${ }^{241} \mathrm{Am}$ was detected in 4 of these samples. For Case 0269 , the activity ratio ${ }^{241} \mathrm{Pu} /{ }^{241} \mathrm{Am}$ was estimated to be $8.0 \pm 0.9$ for the liver, and $2.9 \pm 0.2$ for the bone samples, indicating significantly different biokinetics of $\mathrm{Pu}$ and $\mathrm{Am}$ in these organs [resulting from a single, acute intake of soluble $\left.\mathrm{Pu}\left(\mathrm{NO}_{3}\right)_{4}\right]$. For Case 0720, the activity ratio ${ }^{241} \mathrm{Pu} /{ }^{241} \mathrm{Am}$ was estimated to be $14.3 \pm 2.7$ in liver, and $4.7 \pm 1.7$ for lung (resulting from inhalation of highly insoluble $\mathrm{PuO}_{2}$ particles). The ${ }^{241} \mathrm{Pu}$ and ${ }^{241} \mathrm{Am}$ activities measured in the lungs (at death) represent the amounts of these isotopes still present in 'intact' particles, whereas the higher ${ }^{241} \mathrm{Pu} /{ }^{241} \mathrm{Am}$ ratio in liver indicates preferential retention of translocated elemental Pu over Am in this organ.

As summarized in Table $2,{ }^{234} \mathrm{U},{ }^{235} \mathrm{U}$ and ${ }^{238} \mathrm{U}$ isotopes were successfully measured in all SF-ICP-MS analyzed samples. For Case $1028,{ }^{236} \mathrm{U}$ was measured by SF-ICP-MS in all samples. The presence of non-naturally occurring ${ }^{236} \mathrm{U}$, is a clear indicator that the uranium had been irradiated or highly enriched uranium (HEU) was reprocessed [58]. The isotope ${ }^{236} \mathrm{U}$ could not previously be measured at USTUR (using $\alpha$-spectrometry). The ${ }^{236} \mathrm{U} /{ }^{238} \mathrm{U}$ atom ratio measured by SF-ICP-MS ranged from 0.00091 in spleen to a maximum value of 0.00606 in lung and femur. The lower values of ${ }^{236} \mathrm{U} /{ }^{238} \mathrm{U}$ in spleen and kidney are attributed to a higher 'dilution' of the inhaled HEU with environmental natural U from dietary intake (over almost 40 years since exposure). Table 3 summarizes the results of the statistical and regression analyses of these intercomparisons. With the Wilcoxon matched-pairs test, no statistical significances were observed between results of ${ }^{239+240} \mathrm{Pu},{ }^{241} \mathrm{Am}$ and ${ }^{234,235,238} \mathrm{U}$ activity concentrations measured by SF-ICP-MS and AS. Likewise, no statistical significance was observed between the results of SF-ICP-MS and KPA for U analysis. The SF-ICP-MS results were strongly correlated with the results from AS $\left(R^{2} \geq 0.996\right)$ or KPA $\left(R^{2}=0.985\right)$.

Table 3. Statistical analysis results for the comparison of SF-ICP-MS $v s$. $\alpha$-spectrometry (AS) and KPA for ${ }^{239+240} \mathrm{Pu},{ }^{241} \mathrm{Am}$ and ${ }^{234,235,238} \mathrm{U}$ concentration $\left(\mathrm{Bq} \mathrm{kg}^{-1}\right)$ measurements.

\begin{tabular}{|c|c|c|c|c|c|}
\hline \multirow[t]{2}{*}{ Techniques } & \multirow[t]{2}{*}{ Nuclides } & \multirow{2}{*}{$\begin{array}{c}\text { Wilcoxon } \\
\text { matched-pairs test } \\
(p \text {-value })\end{array}$} & \multicolumn{3}{|c|}{ Weighted regression analysis } \\
\hline & & & Slope $(a)$ & $y$-intercept $(b)$ & Correlation $\left(R^{2}\right)$ \\
\hline SF-ICP-MS vs. AS & ${ }^{239+240} \mathrm{Pu}$ & n.s. $(0.084)$ & $1.033 \pm 0.002$ & $-0.008 \pm 0.010$ & 0.9970 \\
\hline SF-ICP-MS $v s$. AS & ${ }^{241} \mathrm{Am}$ & n.s. $(0.375)$ & $0.953 \pm 0.022$ & $-0.157 \pm 0.240$ & 0.9961 \\
\hline SF-ICP-MS $v s$. AS & ${ }^{234,235,238} \mathrm{U}$ & n.s. $(0.844)$ & $1.011 \pm 0.012$ & $-0.035 \pm 0.010$ & 0.9969 \\
\hline SF-ICP-MS vs. KPA & ${ }^{234,235,238} \mathrm{U}$ & n.s. $(0.313)$ & $1.042 \pm 0.012$ & $-0.0005 \pm 0.0002$ & 0.9848 \\
\hline
\end{tabular}

n.s. - not significant. 
Excellent agreement between SF-ICP-MS and AS ${ }^{239+240} \mathrm{Pu}$ results was observed, with only $3.3 \pm 0.2 \%$ positive bias and SF-ICP-MS yielding higher values. This small bias is within the range of systematic difference between ${ }^{239+240} \mathrm{Pu}$ determined by ICP-MS and $\alpha$-spectrometry reported in the literature $[59,60]$. Negative bias of $4.7 \pm$ $2.2 \%$ was observed for ${ }^{241} \mathrm{Am}$. The SF-ICP-MS results for ${ }^{234,235,238} \mathrm{U}$ were identical to AS, i.e., no significant bias was observed $(1.1 \pm 1.2 \%)$. When SF-ICP-MS results for uranium were compared to KPA, $4.2 \pm 1.2 \%$ positive bias was observed. In all regression analyses, the $y$-axis intercepts $(b)$ were statistically indistinguishable from zero.

\subsection{Actinide elemental bio-imaging using LA-ICP-MS}

Fig. 1 shows elemental distribution maps for ${ }^{241} \mathrm{Am},{ }^{232} \mathrm{Th}$ and ${ }^{238} \mathrm{U}$ obtained from a $30 \mu \mathrm{m}$-thick tissue section of cryogenically frozen pulmonary LN (from Case 0846).
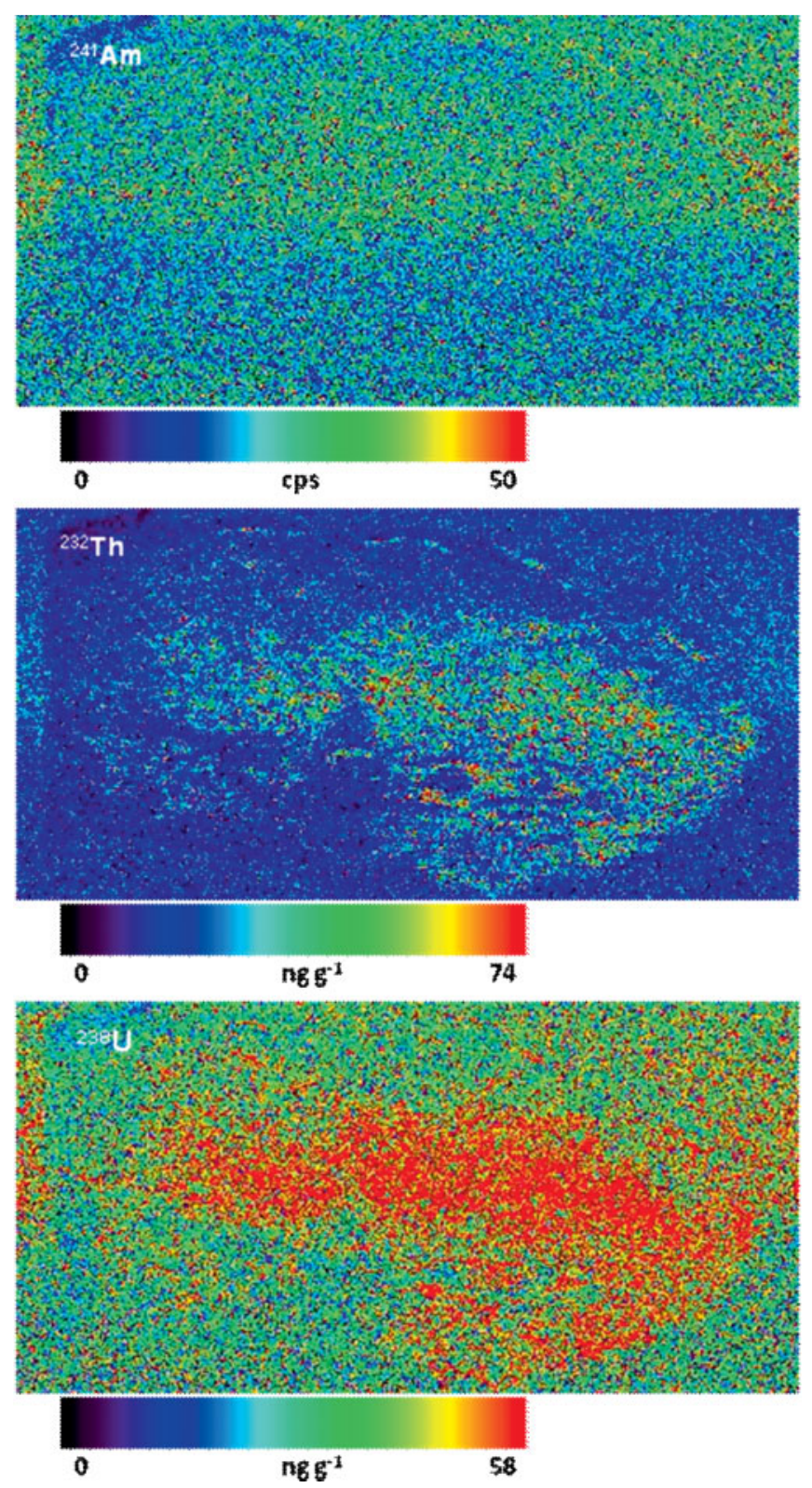

Fig. 1. Elemental distribution map of ${ }^{241} \mathrm{Am}$ (top), ${ }^{232} \mathrm{Th}$ (middle) and ${ }^{238} \mathrm{U}$ (bottom) in pulmonary lymph node from USTUR Case 0846.
The ${ }^{241} \mathrm{Am}$ signal (at $m / z=241$ ) was not distinguishable from background noise. This indicates that the ${ }^{241} \mathrm{Am}$ concentration in the tissue is below previously reported LOD of $1 \mathrm{ng} \mathrm{g}^{-1}\left(127 \mathrm{kBq} \mathrm{kg}^{-1}\right)$ for a currently used LA-ICP-MS system [50]. Signals at $m / z=232$ and 238 were detected and quantified as thorium $\left({ }^{232} \mathrm{Th}\right)$ and uranium $\left({ }^{238} \mathrm{U}\right)$ using the method described previously [47]. The concentrations of ${ }^{232} \mathrm{Th}$ and ${ }^{238} \mathrm{U}$ in the section of lymph node ranged up to $74 \mathrm{ng} \mathrm{g}^{-1}\left(0.3 \mathrm{~Bq} \mathrm{~kg}^{-1}\right)$ and $58 \mathrm{ng} \mathrm{g}^{-1}\left(0.72 \mathrm{~Bq} \mathrm{~kg}^{-1}\right)$, respectively. These concentration values are consistent with other USTUR data for ${ }^{232} \mathrm{Th}$ and ${ }^{238} \mathrm{U}$ in thoracic $\mathrm{LN}$ and lung samples from persons chronically (non-occupationally) exposed to natural Th and $\mathrm{U}$ by inhalation [50]. Fig. ?? shows inhomogeneous distributions of ${ }^{232} \mathrm{Th}$ and ${ }^{238} \mathrm{U}$ in the lymph node, with similar localization. This indicates local aggregation of particulate material. In contrast, the distribution of natural uranium in rat and human brain tissue has been shown by LA-ICP-MS to be uniform $[48,49]$.

\section{Conclusions}

The radioanalytical techniques and instrumentation used at the US Transuranium and Uranium Registries for $\mathrm{Pu}$, $\mathrm{Am}$ and $\mathrm{U}$ isotopic determination in human tissues samples have been reviewed. The results of inter-comparing ${ }^{239+240} \mathrm{Pu},{ }^{241} \mathrm{Am}$ and ${ }^{234,235,238} \mathrm{U}$ determinations by SF-ICPMS, $\alpha$-spectrometry (AS) and kinetic phosphorescence analysis (KPA) show excellent agreement between these different techniques. It has been shown that SF-ICP-MS provides a major advance over AS and KPA in enabling the measurement of the ${ }^{240} \mathrm{Pu} /{ }^{239} \mathrm{Pu}$ atom ratio, the $\beta$-emitter ${ }^{241} \mathrm{Pu}$, and anthropogenic ${ }^{236} \mathrm{U}$. Application of AS and SF-ICPMS techniques to actinide determination in human tissue samples provides more information from a single sample analysis. For the first time, ${ }^{241} \mathrm{Am}$ and ${ }^{241} \mathrm{Pu}$ were measured in human tissues using SF-ICP-MS. The application of LA-ICP-MS to elemental bio-imaging is a promising new USTUR research tool to better understand actinide distribution within human tissues.

Acknowledgment. This work was financially supported by a grant from the US Department of Energy, Office of Illness and Injury Prevention Programs (HS-13) to Washington State University; under award number DE-FG06-92EH889181. The authors would like to thank Ms. Dorothy B. Stuit (USTUR) for her support in laboratory work and Ms. Stacey L. McCord (USTUR) for compilation of health physics data.

\section{References}

1. McInroy, J. F., Kathren, R. L., Swint, M. J.: Distribution of plutonium and americium in whole bodies donated to the United States Transuranium Registry. Radiat. Prot. Dosim. 26, 151 (1989).

2. Norwood, W. O., Newton, C. E.: US Transuranium Registry study of thirty autopsies. Health Phys. 28, 669 (1975).

3. Breitenstein, B. D.: The US Transuranium Registry. In: Actinides in Man and Animals. (Wrenn, M. E., ed.) RD Press, Salt Lake City, UT (1981).

4. McInroy, J. F., Boyd, H. A., Eutsler, B. C., Romero, D.: The US Transuranium Registry report of the ${ }^{241} \mathrm{Am}$ content of a whole body. Part IV: Preparation and analysis of the tissues and bones. Health Phys. 49, 587 (1985).

5. Boyd, H. A., Eutsler, B. C., McInroy, J. F.: Determination of americium and plutonium in autopsy tissue: methods and problems. In: Actinides in Man and Animals. (Wrenn, M. E., ed.) RD Press, Salt Lake City, UT (1981). 
6. Gonzales, E. R., Willis, L. C.: Anion exchange isolation of uranium from prepared tissue solutions. LA-10300-M, RT400-1RT400-6 (1987).

7. Qu, H., Stuit, D., Glover, S. E., Love, S. F., Filby, R. H.: Preconcentration of plutonium and americium using the Actinide-CU ${ }^{\mathrm{TM}}$ Resin for human tissue analysis. J. Radioanal. Nucl. Chem. 234, 175 (1998).

8. Moody, C. A., Glover, S. E., Stuit, D. B., Filby, R. H.: Pre-concentration and separation of thorium, uranium, plutonium and americium in human soft tissues by extraction chromatography. J. Radioanal. Nucl. Chem. 234, 183 (1998).

9. United States Transuranium and Uranium Registries Radioanalytical Procedure Manual.: Pre-concentration of plutonium and americium from tissue samples (USTUR 150).

10. United States Transuranium and Uranium Registries Radioanalytical Procedure Manual.: Separation and purification of plutonium from americium in pre-concentrated samples (USTUR 220).

11. United States Transuranium and Uranium Registries Radioanalytical Procedure Manual: Separation and Purification of Americium from Pre-concentrated Tissue Solutions (USTUR 310).

12. United States Transuranium and Uranium Registries Radioanalytical Procedure Manual.: Anion exchange isolation of uranium from prepared tissue solutions (USTUR 400).

13. Filipy, R. E., Khokhryakov, V. F., Suslova, K. G., Romanov, S. H., Stuit, D. B., Aladova, E. E., Kathren, R. L.: Analysis for actinides in tissue samples from plutonium workers of two countries. J. Radioanal. Nucl. Chem. 234, 171 (1998).

14. Popplewell, D. S., Ham, G. J., Johnson, T. E., Barry, S. F.: Plutonium in autopsy tissues in Great Britain. Health Phys. 49, 304 (1985).

15. Horwitz, E. P., Dietz, M. L., Chiarizia, R., Diamond, H., Essling, A. M., Graczyk, D.: Separation and preconcentration of uranium from acidic media by extraction chromatography. Anal. Chim. Acta 266, 25 (1992)

16. Horwitz, E. P., Chiarizia, R., Dietz, M. L., Diamond, H., Nelson, D. M.: Separation and preconcentration of actinides from acidic media by extraction chromatography. Anal. Chim. Acta 281, 361 (1993).

17. Lee, S. H., La Rosa, J., Gastaud, J., Povinec, P. P.: The development of sequential separation methods for the analysis of actinides in sediments and biological materials using anionexchange resins and extraction chromatography. J. Radioanal. Nucl. Chem. 263, 419 (2005).

18. Maxwell III, S. L., Faison, D. M.: Rapid column extraction method for actinides and strontium in fish and other animal tissue samples. J. Radioanal. Nucl. Chem. 275, 605 (2008).

19. Nichols, S.: New fecal method for plutonium and americium. J. Radioanal. Nucl. Chem. 250, 117 (2001).

20. Kuwabara, J., Noguchi, H.: Development of rapid bioassay method for plutonium. J. Radioanal. Nucl. Chem. 252, 273 (2002).

21. Tolmachyov, S. Y., Kuwabara, J., Noguchi, H.: Flow injection extraction chromatography with ICP-MS for thorium and uranium determination in human body fluids. J. Radioanal. Nucl. Chem. 261, 125 (2004).

22. Thakkar, A.: Rapid sequential separation of actinides using Eichrom's extraction chromatographic material. J. Radioanal. Nucl. Chem. 248, 453 (2001).

23. Maxwell III, S. L., Culligan, B. K.: Rapid column extraction method for actinides in soil. J. Radioanal. Nucl. Chem. 270, 699 (2006).

24. Maxwell III, S. L.: Rapid analysis of emergency urine and water samples. J. Radioanal. Nucl. Chem. 275, 497 (2008).

25. Fisenne, I. M., Perry, P. M., Chu, N. Y., Harley, N. A.: Measured ${ }^{234,238} \mathrm{U}$ and fallout ${ }^{239,240} \mathrm{Pu}$ in human bone ash from Nepal and Australia: skeletal alpha dose. Health Phys. 44, 457 (1983).

26. Bunzl, K., Kracke, W.: Fallout ${ }^{239 / 240} \mathrm{Pu}$ and ${ }^{238} \mathrm{Pu}$ in human tissues from the Federal Republic of Germany. Health Phys. 44(Suppl. 1), 441 (1983).

27. Popplewell, D. S., Ham, G. J.: Distribution of plutonium and americium in tissues from a human autopsy case. J. Radiol. Prot. 9, 159 (1989).

28. Yamamoto, M., Hoshi, M., Sakaguchi, A., Shinohara, K., Kurihara, O., Apsalikov, K. N.,Gusev, B. I.: Plutonium and uranium in human bones from areas surrounding the Semipalatinsk nuclear test site. J. Radiat. Res. 47(Suppl. A), A85 (2006).

29. United States Transuranium and Uranium Registries Radioanalytical Procedure Manual: Electrodeposition of americium, plutonium, thorium and uranium (USTUR 510).

30. Boyd, H. A., Eutsler, B. C.: Electroplating americium, plutonium and uranium. LA-10300-M. RT500-1-RT500-5 (1987).

31. Glover, S. E., Filby, R. H., Clark, S. B., Grytdal, S. P.: Optimization and characterization of a sulfate based electrodeposition method for alpha-spectroscopy of actinide elements using chemometric analysis. J. Radioanal. Nucl. Chem. 234, 213 (1998).

32. Bushaw, B. A.: Advanced analytical techniques. In: Biokinetics and Analysis of Uranium in Man. Proceedings of a colloquium, Joint Center for Graduate Study. Richland, WA (1984).

33. Hedaya, M. A., Birkenfeld, H. P., Kathren, R. L.: A sensitive method for the determination of uranium in biological samples utilizing kinetic phosphorescence analysis (KPA). J. Pharm. Biomed. Anal. 15, 1157 (1997).

34. Brina, R., Miller, A. G.: Direct detection of trace levels of uranium by laser-induced kinetic phosphorimetry. Anal. Chem. 64, 1413 (2002).

35. Elliston, J. T., Glover, S. E., Filby, R. H.: The determination of natural uranium in human tissues by recovery corrected kinetic phosphorescence analysis. J. Radioanal. Nucl. Chem. 248, 487 (2001).

36. Elliston, J. T., Glover, S. E., Filby, R. H.: Comparison of direct kinetic phosphorescence analysis and recovery corrected kinetic phosphorescence analysis for the determination of natural uranium in human tissues. J. Radioanal. Nucl. Chem. 263, 301 (2005).

37. Becker, J. S.: Mass spectrometry of long-lived radionuclides. Spectrochim Acta B Atom. Spectros. 58, 1757 (2003).

38. Lariviere, D., Taylor, V. F., Evans, R. D., Cornett, R. J.: Radionuclide determination in environmental samples by inductively coupled plasma mass spectrometry. Spectrochim. Acta B Atom. Spectros. 61, 877 (2006).

39. Ketterer, M. E., Szechenyi, S. C.: Determination of plutonium and other transuranic elements by inductively coupled plasma mass spectrometry: a historical perspective and new frontiers in the environmental sciences. Spectrochim. Acta B At. Spectros. 63, 719 (2008).

40. Kelley, J. M., Bond, L. A., Beasley, T. M.: Global distribution of $\mathrm{Pu}$ isotopes and ${ }^{237} \mathrm{~Np}$. Sci. Total. Environ. 237-238, 483 (1999).

41. Varga, Z.: Application of inductively coupled plasma sector field mass spectrometry for low-level environmental americium-241 analysis. Anal. Chim. Acta. 587, 165 (2007).

42. Varga, Z., Surányi, G., Vajda, N., Stefánka,Z.: Rapid sequential determination of americium and plutonium in sediment and soil samples by ICP-SFMS and alpha-spectrometry. Radiochim. Acta. 95, 81 (2007).

43. Cizdziel, J. V., Ketterer, M. E., Farmer, D., Faller, S. H., Hodge, V. F.: ${ }^{239,240,241} \mathrm{Pu}$ fingerprinting of plutonium in western US soils using ICPMS: solution and laser ablation measurements. Anal. Bioanal. Chem. 390, 521 (2008).

44. Boulyga, S. F., Becker, J. S.: Determination of uranium isotopic composition and ${ }^{236} \mathrm{U}$ content of soil samples and hot particles using inductively coupled plasma mass spectrometry. Fresenius' Anal. Chem. 370, 612 (2001).

45. Parrish, R. R., Thirlwall, M. F., Pickford, C., Horstwood, M., Gerdes, A., Anderson, J., Coggon, D.: Determination of ${ }^{238} \mathrm{U} /{ }^{235} \mathrm{U}$, ${ }^{236} \mathrm{U} /{ }^{238} \mathrm{U}$ and uranium concentration in urine using SF-ICP-MS and MC-ICP-MS: an interlaboratory comparison. Health Phys. 90, 127 (2006).

46. Austin, C., Hare, D., Rozelle, A. R., Robinson, W. H., Grimm, R., Doble, P.: Elemental bio-imaging of calcium phosphate crystal despoits in knee samples from arthritic patients. Metallomics 1, 141 (2009).

47. Hare, D., Burger, F., Austin, C., Fryer, F., Grimm, R., Reedy, B., Scolyer, R. A., Thompson, J. F., Doble, P.: Elemental bio-imaging of melanoma in lymph node biopsies. Analyst 134, 450 (2009).

48. Zoriy, M. V., Dehnhardt, M., Reifenberger, G., Zilles, K., Becker, J. S.: Imaging of $\mathrm{Cu}, \mathrm{Zn}, \mathrm{Pb}$ and $\mathrm{U}$ in human brain tumor resections by laser ablation inductively coupled plasma mass spectrometry. Int. J. Mass Spectrom. 257, 27 (2006). 
49. Becker, J. S., Dobrowolska, J., Zoriy, M., Matusch, A.: Imaging of uranium on rat brain sections using laser ablation inductively coupled plasma mass spectrometry: a new tool for the study of critical substructures affined to heavy metals in tissues. Rapid Commun. Mass Spectrom. 22, 2768 (2008).

50. Hare, D., Tolmachev, S. Y., James, A. C., Bishop, D., Austin, C., Fryer, F., Doble, P.: Elemental bio-imaging of thorium, uranium and plutonium in tissues from occupationally exposed former nuclear workers. Anal. Chem. 82, 3176 (2010).

51. Elliston, J. T.: The distribution of uranium in human tissues. $\mathrm{PhD}$ Thesis. Washington State University, Richland, WA (2001).

52. Brodsky, A., Wald, N.: Experiences with early emergency response and rules of thumb. In: Public Protection from Nuclear, Chemical, and Biological Terrorism. Proceedings of the Health Physics Society 2004 Summer School, Medical Physics Publishing, Madison, WI (2004).

53. Ketterer, M. E., Hafer, K. M., Mietelski, J. W.: Resolving Chernobyl vs. global fallout contributions in soils from Poland using Plutonium atom ratios measured by inductively coupled plasma mass spectrometry. J. Environ. Radioact. 73, 183 (2004).
54. Ketterer, M. E., Hafer, K. M., Jones, V. J., Appleby, P. G.: Rapid dating of recent sediments in Loch Ness: inductively coupled plasma mass spectrometric measurements of global fallout plutonium. Sci. Total Environ. 322, 221 (2004).

55. Longerich, H. P.: The application of isotope dilution to ICP-MS. At. Spectros. 10, 4 (1989).

56. ICRP Publication 38: Radionuclide Transformations Energy and Intensity of Emissions. Elsevier, Amsterdam (1983).

57. Motulsky, H. J.: GraphPad InStat 3.0 user's guide. GraphPad Software, Inc., San Diego (1999).

58. Richter, S., Alonso, A., De Bolle, W., Wellum, R., Taylor, P. D. P.: Isotopic "fingerprints" for natural uranium ore samples. Int. J. Mass Spectrom. 193, 9 (1999).

59. Michel, H., Ketterer, M., Barci-Funel, G.: ICP-MS analysis of plutonium activities and ${ }^{240} \mathrm{Pu} /{ }^{239} \mathrm{Pu}$ ratio in alpha spectrometry planchet deposits. J. Radioanal. Nucl. Chem. 273, 485 (2007).

60. Varga, Z., Surányi, G., Vajda, N., Stefánka, Z.: Determination of plutonium and americium in environmental samples by inductively coupled plasma sector field mass spectrometry and alpha spectrometry. Microchem. 85, 39 (2007). 